\title{
MENINGKATKAN HASIL BELAJAR SISWA KELAS XII SMA NEGERI 1 AMBUNTEN DENGAN MENERAPKAN METODE KREATIVITAS
}

\author{
Arief Harmono Satriyotomo ${ }^{1}$, Joni Santoso ${ }^{2}$ \\ Pengajar SMA Negeri 1 Ambunten ${ }^{1,2}$ \\ joni.santoso19@yahoo.co.id ${ }^{2}$
}

\begin{abstract}
ABSTRAK
Masalah pendidikan kita juga bisa berprestasi melalui kreativitas para pelajar Indonesia yang saat ini menempuh pendidikan di luar negeri. Beberapa waktu lalu kita telah berhasil memenangkan kompetisi ilmu pengetahuan dan teknologi se Asia melalui duta bangsa para pelajar SMP, SMA maupun perguruan tinggi. Olimpiade tersebut membuktikan bahwa sebenarnya kita mampu bersaing dengan bangsa lain dan mampu menunjukkan kualitas bangsa Indonesia di mata internasional. Perbedaan kita dengan kemampuan pelajar asing mungkin hanya terletak pada masalah kreativitas dan ketekunan. tujuannya adalah : 1) Untuk mengetahui kreativitas siswa kelas XII SMA Negeri 1 Ambunten. 2) Untuk mengetahui dampak positif kreativitas terhadap prestasi belajar siswa kelas XII SMA Negeri 1 Ambunten. 3) Untuk mengetahui kontribusi kreativitas terhadap prestasi belajar siswa Kelas XII dalam upaya melanjutkan ke jenjang pendidikan yang lebih tinggi.

Metode yang digunakan dalam penelitian ini menggunakan rancangan penelitian tindakan (action research). Populasi siswa kelas XII Negeri 1 Ambunten tahun ajaran 2014-2015 terdiri dari enam kelas, dengan jumlah siswa 250 orang. Adapun sampel yang akan diteliti sejumlah 19 orang, Pengambilan sampel dilakukan dengan teknik random sampling (acak). Random ini dilakukan dengan cara pengundian.

Hasil penelitian menunjukkan bahwa (1) Siswa yang dalam proses pembelajaran mempunyai sikap, kerjasama dan motivasi yang baik, akan berpengaruh besar dalam menunjang prestasi belajarnya. Semakin baik tingkat kreativitas, maka akan semakin baik pula prestasi belajar yang dicapai siswa. (2) Dampak positif kreativitas terhadap prestasi belajar: a) Menemukan ide/gagasan baru, b) Meningkatkan kreasi, c) Meningkatkan Apresiasi, d) Menumbuhkan rasa percaya diri, e) Menanamkan rasa tanggung jawab, f) Sikap dan tingkah laku yang baik, g) Nilai social, h) Menumbuhkan rasa disiplin; (3)Kontribusikreativitas terhadap prestasi belajarmemberikan kontribusi terhadap prestasi belajar siswa. Kontribusi tersebut berupa kemampuan siswa dalam mencetuskan ide/gagasan, berkreasi dalam setiap mata pelajaran dan mampu mengapresiasikan setiap mata pelajaran yang telah diberikan, sehingga mudah bagi siswa tersebut untuk mengikuti, menerima dan mengerti setiap pelajaran yang diberikan dan akhirnya dapat memberikan prestasi belajar yang memuaskan.
\end{abstract}

Kata kunci : menciptakan sikap kreatif dan positif, prestasi belajar, metode kreativitas, penelitian tindakan kelas (PTK).

\section{PENDAHULUAN}

Dalam penelitian tentang kreativitas pernah dilakukan para ahli menunjukkan bahwa siswa yang kreatif mempunyai tingkat kemandirian, agresif dan prestasi belajar yang lebih baik dibandingkan siswa yang pasif (Bafadal, 1994). Untuk itu perlu ditumbuhkembangkan pada diri setiap siswa terutama kelas XII agar menjadi siswa yang kreatif dan mampu meningkatkan prestasi belajar Geografi. Guru dan orang tua harus ikut andil dalam menciptakan kreativitas siswa, namun demikian siswa juga mempunyai jiwa yang besar dan semangat tinggi dalam meningkatkan prestasi belajar. 
Sejauh ini masalah kreativitas kurang digali secara maksimal baik oleh guru, siswa maupun orang tua (Meleong, 2000). Untuk menciptakan generasi yang handal dan mampu bersaing pada jenjang pendidikan yang lebih tinggi, maka siswa kelas XII utamanya harus memenuhi standar siswa yang kreatif dan prestasi belajar yang lumayan. Penulis akan menuangkannya dalam skripsi dengan judul "Meningkatkan Hasil Belajar Siswa Kelas XII SMA Negeri 1 Ambunten Dengan Menerapkan Metode Kreativitas".

\section{METODE PENELITIAN \\ Rancangan Penelitian}

Rancangan dalam penelitian ini menggunakan rancangan penelitian tindakan (action research). Penerapan penelitian tindakan di dalam kelas diharapkan mampu mendorong guru untuk memiliki kesadaran diri melakukan refleksi dan kritik diri terhadap aktivitas pembelajaran. Penelitian tindakan (action research) merupakan proses daur ulang, mulai tahap perencanaan, pelaksanaan tindakan dan pemantauan, refleksi yang mungkin diikuti dengan perencanaan ulang (Waseso, 1994). Rancangan dalam penelitian ini direncanakan melalui beberapa tahap perencanaan, antara lain : (1) refleksi awal, (2) peneliti merumuskan permasalahan secara operasional, (3) peneliti merumuskan hipotesis tindakan, dan (4) menetapkan dan merumuskan rancangan tindakan.

\section{Instrumen Penelitian}

Ada lima jenis instrumen yang digunakan dalam penelitian tindakan, yaitu : observasi, wawancara, catatan lapangan, angket dan dokumentasi (Zuriah, 2003). Dalam penelitian ini instrumen penelitian yang digunakan meliputi (a) observasi, (b) wawancara dan (c) dokumentasi.
1. Observasi

Observasi merupakan pengamatan dan pencatatan secara sistematik terhadap gejala yang tampak pada objek penelitian. Pengamatan dan pencatatan ini dilakukan terhadap objek di tempat kejadian atau berlangsungnya peristiwa (Zuriah, 2003). Ada dua jenis observasi yang dilakukan antara lain : (1) observasi langsung, yaitu observasi yang dilakukan dimana observer berada bersama objek yang diselidiki, dan (2) observasi tidak langsung, yaitu observasi atau pengamatan yang dilakukan tidak pada saat berlangsungnya suatu peristiwa yang akan diteliti. Penelitian ini melakukan observasi langsung terhadap kreativitas siswa kelas XII dan prestasi belajarnya melalui kegiatan belajar mengajar. Dalam teknik penelitian ini dilakukan catatan terhadap hasil observasi dengan menggunakan daftar cek (chek list).

Dalam penelitian ini metode observasi yang dilakukan peneliti adalah pengamatan berperan serta. Pengamatan berperan serta dalam penelitian yang bercirikan interaksi sosial akan memakan waktu yang cukup lama antar peneliti dengan subjek dalam, lingkungan subjek dan selama itu data yang dikumpulkan dalam bentuk catatan lapangan secara sistematis serta berlaku tanpa gangguan (Meleong, 2000). Dalam penelitian ini menggunakan teknikteknik dasar penelitian kualitatif.

Tahapan pengamatan berperan serta dalam penelitian kualitatif antara lain (1) diawali dari pengamatan yang bersifat memeriksa (descriptive observations) secara luas dengan menggambarkan situasi sosial secara umum yang ada di lokasi penelitian, (2) dilanjutkan dengan pengamatanpengamatan yang lebih terfokus (focused observations) untuk menemukan kategori-kategori utama 
tentang fokus penelitian, dan (3) mengadakan pengamatan yang bersifat selektif (selective observations) untuk menemukan kategori-kategori yang lebih rinci tentang sub-sub fokus penelitian (Spradly, 1980).

Ketiga tahap tersebut akan dilakukan oleh peneliti dalam penelitian Kreativitas Meningkatkan Prestasi Belajar Dalam Proses Belajar Mengajar pada Siswa Kelas XII SMA Negeri 1 Ambunten.

Spradly (1980) menjabarkan lima tipe keterlibatan peneliti dalam partisipasi observasi sebagai berikut,

a. Tidak berpartisipasi (non participation)

Pada tipe ini peneliti dalam melakukan penelitian tidak berpartisipasi, artinya peneliti hanya melakukan pengamatan (melihat) secara pasif dan menjauhi agar tidak terlibat dalam aktivitas objek penelitian.

b. Partisipasi pasif (passive participation)

Dalam tahap ini peneliti ikut atau berada dalam objek penelitian, tetapi tidak berpartisipasi atau interaksi dengan objek penelitian. Peneliti hanya sebagai penonton saja.

c. Partisipasi moderat (moderat participation)

Peneliti sudah pada konteks untuk menjaga keseimbangan antara seseorang yang berada di dalam (insider) dan menjadi seseorang yang berada di luar (outsider) ataupun terlibat dan mengamati.

d. Partisipasi aktif (active participation)

Pada tahap ini peneliti secara aktif melakukan apa yang dilakukan oleh personel-personel sekolah.

e. Partisipasi secara total (Complete or ordinary participation)

Tipe ini merupakan tahap tertinggi dalam keterlibatan peneliti sebagai observer participant. Peneliti total melakukan seperti apa yang dikerjakan oleh personel-personel sekolah dalam memperoleh data penelitian.

2. Wawancara

Wawancara merupakan salah satu prosedur terpenting untuk mengumpulkan data dalam penelitian kualitatif, karena banyak informasi yang diperoleh peneliti melalui wawancara. Wawancara merupakan metode pengumpulan data yang menghendaki komunikasi langsung antara peneliti dengan responden (Zuriah, 2003). Wawancara adalah suatu percakapan yang bertujuan memperoleh konstruksi yang terjadi sekarang tentang orang, kejadian, aktivitas, organisasi, perasaan, motivasi, pengakuan, kerisauan dan sebagainya (Arifin, 1998). Maksud wawancara antara, lain untuk mengkonstruksi mengenai orang, kejadian, kegiatan, organisasi, perasaan, motivasi, tuntutan kepedulian dan lain-lain (Moleong, 2000).

Peneliti melakukan wawancara untuk memperoleh data sesuai dengan kenyataan pada saat peneliti melakukan wawancara. Wawancara dalam penelitian ini di tujukan kepada guru kelas dan siswa kelas XII SMA Negeri 1 Ambunten. Wawancara dalam penelitian ini menggunakan jenis wawancara mendalam yang tak berstruktur. Dengan wawancara tak berstruktur akan diperoleh informasi sebanyak-banyaknya yang rahasia dan sensitif sifatnya, serta memungkinkan sekali dicatat semua respons efektif informan yang tampak selama wawancara berlangsung (Bafadal, 1994). Dalam pelaksanaan wawancara terlebih dahulu disusun garis-garis besar pertanyaan yang disampaikan kepada informan berdasarkan pada fokus dan sub fokus penelitian. 
3. Dokumentasi

Pendokumentasian adalah cara mengumpulkan data melalui peninggalan tertulis, terutama berupa arsip-arsip dan termasuk juga bukubuku tentang pendapat, teori, dalil atau hukum-hukum lain yang berhubungan dengan masalah penelitian (Zuriah, 2003).

Dokumen dan record dapat digunakan untuk keperluan penelitian, karena (1) merupakan sumber yang stabil, kaya dan mendorong, (2) berguna sebagai bukti untuk semua pengujian, (3) sifatnya alamiah sesuai dengan konteks, (4) hasil pengkajian akan membuka kesempatan untuk lebih memperluas pengetahuan yang diselidiki.

\section{HASIL PENELITIAN}

Hasil penelitian tentang hasil kreativitas terhadap prestasi belajar siswa kelas XII SMA Negeri 1 Ambunten Kabupaten Sumenep disajikan dalam bentuk tabel dan dilakukan pembahasan. Hasil penelitian ini akan disajikan beberapa tabel yang menunjukkan tingkat kreativitas siswa kelas XII dan prestasi belajarnya. Laporan hasil penelitian akan memberikan paparan data dan temuan penelitian.

Kegiatan yang dilaksanakan di kelas XII selama bulan Agustus telah memenuhi semua mata pelajaran, sehingga dapat diketahui bahwa setiap harinya siswa mengikuti pelajaran yang diajarkan oleh guru mata pelajaran. Dari pengamatan selama satu bulan diperoleh data yang menunjukkan adanya beberapa siswa yang menonjol dalam bersikap dan menunjukkan sikap aktif dan kreatif dalam mengikuti pelajaran. Sikap aktif dan kreatif itu diwujudkan dalam bentuk bertanya, mengemukakan ide, sikap dan kemampuan berkreasi serta kepekaan cita rasa.

\section{Paparan Data}

Berdasarkan langkah-langkah penelitian yang dilakukan oleh peneliti, paparan data ini akan memaparkan proses kegiatan belajar mengajar di kelas XII SMA Negeri 1 Ambunten Kabupaten Sumenep.

Gambaran umum kegiatan belajar mengajar setiap mata pelajaran dilakukan setiap hari kecuali hari libur. Jadwal kegiatan belajar mengajar sesuai dengan peraturan yang telah ditetapkan sekolah. Berikut ini paparan data proses belajar mengajar yang dilaksanakan dalam satu bulan yaitu bulan Agustus berdasarkan mata pelajaran yang telah diajarkan pada siswa kelas XII.

a. Pelajaran Pendidikan Pancasila dan Kewarganegaraan

b. Pelajaran Bahasa Indonesia

c. Pelajaran Matematika

d. Pelajaran Biologi

e. Pelajaran Geografi

f. Pelajaran Fisika

g. Pelajaran Bahasa Inggris

Semua mata pelajaran tersebut telah diikuti oleh 19 siswa kelas XII dengan baik. Secara umum kegiatan belajar mengajar dapat dijabarkan sebagai berikut :

a. Dalam setiap pertemuan menunjukkan bahwa siswa kelas XII memiliki motivasi belajar yang terlihat kurang tampak.

b. Ada beberapa siswa yang menunjukkan semangat tinggi pada pelajaran tertentu, hal ini disebabkan karena pelajaran tersebut yang paling disukainya.

c. Kualitas siswa dalam belajar secara kualitatif belum terpenuhi, namun secara kuantitatif semua siswa mengalami proses belajar mengajar yang dilakukan.

d. Dalam kegiatan belajar mengajar bersifat menonton, yaitu siswa mendengarkan guru menjelaskan, sehingga kreativitas siswa dalam 
meningkatkan motivasi belajar kurang tampak.

e. Kreativitas siswa tampak pada pelajaran yang paling disenangi, yaitu muncul sikap agresif, berani bertanya, mengutaran ide dan minta penjelasan ulang terhadap pelajaran tersebut.

f. Kegiatan belajar kelompok atau pembagian tugas kelompok dalam pelajaran tertentu menunjukkan kreativitas yang lebih tinggi, namun ada beberapa siswa yang memanfaatkan kesempatan belajar secara berkelompok sebagai kesempatan untuk berbuat ramai.

g. Kegiatan lapangan pada pelajaran tertentu merupakan kegiatan yang paling disenangi oleh siswa kelas XII, sehingga proses pembelajaran dengan mengkaitkan dunia nyata dan lingkungan tampak lebih berperan dalam menumbuhkan kreativitas anak.

Dari paparan data tersebut menunjukkan bahwa pelajaran. tertentu yang diajarkan kepada siswa dapat menumbuhkan kreativitas, keadaan ini akan tampak lebih menonjol bila kegiatan pembelajaran dilakukan di luar kelas atau praktek di lapangan. Kesempatan ini terkadang dimanfaatkan oleh beberapa siswa untuk berbuat kurang sportif seperti ramai sendiri, mengganggu temannya dan kurang konsentrasi terhadap pelajaran.

\section{Temuan Penelitian}

Berdasarkan paparan data dan hasil penelitian terhadap guru dan siswa kelas XII dalam kerangka mencari pengaruh kreativitas dan prestasi belajar, maka ada beberapa temuan penelitian yang mengarah pada kreativitas siswa kelas XII. Temuan tersebut menunjukkan sikap, kerjasama dan motivasi belajar siswa. Dari sikap kreatif akan diketahui prestasi belajar siswa setelah dilakukan proses pembelajaran dan ujian tertulis maupun praktek.

Suasana kelas belum kondusif dan belum ada motivasi belajar pada masing-masing siswa. Hal ini terjadi karena guru terlalu banyak menggunakan metode ceramah dalam menyampaikan materi pelajaran. Bahkan kadang ada siswa yang kadang tidak memperhatikan guru dalam memberikan penjelasan. Pada saat guru memberikan pertanyaan, seakan siswa juga menjawab semaunya sendiri, artinya jawaban itu cenderung meniru apa yang ia lihat pada acaraacara televisi.

Kegiatan pengajaran terkesan variatif karena didukung kegiatan praktek yang melibatkan semua siswa. Tidak ada siswa yang diam, artinya semua diberi tugas dan tanggung jawab dalam mengerjakan setiap pekerjaan yang diberikan oleh guru. Hal ini didukung oleh keaktifan semua siswa dalam kegiatan belajar.

Tabel 1. Data Siswa Kelas XII SMA Negeri 1 Ambunten

\begin{tabular}{lllll}
\hline & & \multicolumn{3}{c}{ Proses Pembelajaran } \\
\cline { 3 - 5 } No & Nama & Sikap & $\begin{array}{c}\text { Kerja- } \\
\text { sama }\end{array}$ & Motivasi \\
\hline 1 & AB & B & B & B \\
\hline 2 & AK & B & C & C \\
\hline 3 & AS & B & B & C \\
\hline 4 & AG & C & B & C \\
\hline 5 & AZ & B & B & B \\
\hline 6 & SH & C & K & C \\
\hline 7 & IA & B & B & B \\
\hline 8 & LF & B & B & B \\
\hline 9 & MFM & B & B & B \\
\hline 10 & MF & C & B & C \\
\hline 11 & MAF & B & B & B \\
\hline 12 & RH & K & C & C \\
\hline 13 & SY & B & C & B \\
\hline 14 & SG & B & B & B \\
\hline 15 & SS & B & B & B \\
\hline 16 & YNA & B & B & B \\
\hline 17 & TW & C & C & K \\
\hline 18 & AF & B & B & B \\
\hline 19 & DY & B & B & B \\
\hline Ket & B Baik & C Cuku & K & \\
\hline 1
\end{tabular}

Ket : $\mathrm{B}=$ Baik, $\mathrm{C}=$ Cukup, $\mathrm{K}=$ Kurang 
Tabel 2. Data Tingkat Kreativitas Siswa Kelas XII SMA Negeri 1 Ambunten

\begin{tabular}{|c|c|c|c|c|}
\hline \multirow[b]{2}{*}{ No } & \multirow[b]{2}{*}{ Nama } & \multicolumn{3}{|c|}{ Tingkat Kreativitas } \\
\hline & & Ide & Kreasi & $\begin{array}{c}\text { Apresi- } \\
\text { asi }\end{array}$ \\
\hline 1 & $\mathrm{AB}$ & $\mathrm{B}$ & $\mathrm{B}$ & $\mathrm{B}$ \\
\hline 2 & $\mathrm{AK}$ & $\mathrm{C}$ & $\mathrm{C}$ & $\mathrm{C}$ \\
\hline 3 & $\mathrm{AS}$ & $\mathrm{K}$ & $\mathrm{C}$ & $\mathrm{C}$ \\
\hline 4 & $\mathrm{AG}$ & $\mathrm{C}$ & $\mathrm{B}$ & $\mathrm{C}$ \\
\hline 5 & $\mathrm{AZ}$ & $\mathrm{B}$ & $\mathrm{B}$ & $\mathrm{B}$ \\
\hline 6 & $\mathrm{SH}$ & $\mathrm{C}$ & $\mathrm{K}$ & $\mathrm{C}$ \\
\hline 7 & IA & $\mathrm{C}$ & $\mathrm{C}$ & $\mathrm{C}$ \\
\hline 8 & LF & $\mathrm{B}$ & $\mathrm{B}$ & $\mathrm{B}$ \\
\hline 9 & MFM & $\mathrm{B}$ & $\mathrm{C}$ & $\mathrm{B}$ \\
\hline 10 & $\mathrm{MF}$ & $\mathrm{C}$ & $\mathrm{C}$ & $\mathrm{B}$ \\
\hline 11 & MAF & $\mathrm{B}$ & $\mathrm{B}$ & $\mathrm{B}$ \\
\hline 12 & $\mathrm{RH}$ & $\mathrm{K}$ & $\mathrm{C}$ & $\mathrm{C}$ \\
\hline 13 & SY & $\mathrm{K}$ & $\mathrm{C}$ & $\mathrm{C}$ \\
\hline 14 & SG & $\mathrm{B}$ & $\mathrm{B}$ & $\mathrm{B}$ \\
\hline 15 & SS & $\mathrm{C}$ & $\mathrm{C}$ & $\mathrm{K}$ \\
\hline 16 & YNA & $\mathrm{B}$ & $\mathrm{B}$ & $\mathrm{B}$ \\
\hline 17 & TW & $\mathrm{C}$ & $\mathrm{C}$ & $\mathrm{K}$ \\
\hline 18 & $\mathrm{AF}$ & $\mathrm{C}$ & $\mathrm{B}$ & $\mathrm{B}$ \\
\hline 19 & DY & B & B & B \\
\hline
\end{tabular}

Ket : B = Baik, C = Cukup, $\mathrm{K}=$ Kurang

Tabel 3. Data Prestasi Siswa Belajar Kelas XII SMA Negeri 1 Ambunten

\begin{tabular}{llll}
\hline \multirow{2}{*}{ No } & \multirow{2}{*}{ Nama } & \multicolumn{2}{c}{ Prestasi Belajar } \\
\cline { 3 - 4 } 1 & AB & B & B \\
\hline 2 & AK & C & C \\
\hline 3 & AS & B & C \\
\hline 4 & AG & C & C \\
\hline 5 & AZ & B & B \\
\hline 6 & SH & C & C \\
\hline 7 & IA & C & B \\
\hline 8 & LF & B & B \\
\hline 9 & MFM & B & B \\
\hline 10 & MF & C & C \\
\hline 11 & MAF & B & B \\
\hline 12 & RH & K & C \\
\hline 13 & SY & C & K \\
\hline 14 & SG & B & B \\
\hline 15 & SS & B & B \\
\hline 16 & YNA & B & B \\
\hline 17 & TW & C & K \\
\hline 18 & AF & B & B \\
\hline 19 & DY & B & B \\
\hline Ket & B B & C Cunter I \\
\hline
\end{tabular}

Ket : $\mathrm{B}=$ Baik, $\mathrm{C}=$ Cukup, $\mathrm{K}=$ Kurang
Tabel 4. Data Proses Pembelajaran, Kreativitas dan Prestasi Belajar Siswa Kelas XII SMA Negeri 1 Ambunten

\begin{tabular}{lllll}
\hline No & Nama & $\begin{array}{c}\text { Proses } \\
\text { ran }\end{array}$ & $\begin{array}{c}\text { Kreati } \\
\text { vitas }\end{array}$ & $\begin{array}{c}\text { Hasil } \\
\text { Belajar }\end{array}$ \\
\hline 1 & AB & B & B & B \\
\hline 2 & AK & C & C & C \\
\hline 3 & AS & C & K & C \\
\hline 4 & AG & C & C & C \\
\hline 5 & AZ & B & B & B \\
\hline 6 & SH & K & K & K \\
\hline 7 & IA & B & C & C \\
\hline 8 & LF & B & B & B \\
\hline 9 & MFM & B & B & B \\
\hline 10 & MF & C & C & C \\
\hline 11 & MAF & B & B & B \\
\hline 12 & RH & K & K & K \\
\hline 13 & SY & C & K & K \\
\hline 14 & SG & B & B & B \\
\hline 15 & SS & B & K & C \\
\hline 16 & YNA & B & B & B \\
\hline 17 & TW & K & K & K \\
\hline 18 & AF & B & B & B \\
\hline 19 & DY & B & B & B \\
\hline Ket & B B B & C Cun & K \\
\hline
\end{tabular}

Ket : $\mathrm{B}=$ Baik, $\mathrm{C}=$ Cukup, $\mathrm{K}=$ Kurang

\section{PEMBAHASAN}

Untuk mengetahui hasil kreativitas terhadap prestasi belajar, dampak positif kreativitas bagi siswa kelas XII dan kontribusi kreativitas bagi siswa kelas XII SMA Negeri 1 Ambunten, maka selanjutnya dilakukan pembahasan terhadap masing-masing topik tersebut.

\section{Kreativitas Terhadap Prestasi belajar}

Berdasarkan hasil penelitian menunjukkan bahwa seorang siswa yang dalam proses pembelajaran mempunyai sikap, kerjasama dan motivasi yang baik, akan berpengaruh besar dalam menunjang prestasi belajarnya. Sebaliknya jika seorang siswa yang mempunyai sikap, kerjasama dan motivasi rendah dalam proses pembelajaran, maka siswa tersebut akan menunjukkan prestasi 
belajar yang rendah. Keadaan ini disebabkan kemampuan masingmasing siswa berbeda. Setiap siswa yang dapat mengembangkan sikap patuh, mendengarkan dan menyimak dengan baik terhadap materi yang disampaikan oleh guru, maka siswa tersebut akan dapat menerima ilmu yang diberikan. Demikian juga dengan kerjasama yang baik terhadap teman dan guru dalam proses pembelajaran akan sangat membantu siswa dalam memecahkan kesulitan yang dihadapi, sehingga dapat mencapai prestasi belajar yang diharapkan. Motivasi yang tinggi akan memberikan kontribusi yang cukup signifikan terhadap prestasi belajar siswa.

Dalam proses pembelajaran menunjukkan adanya keterkaitan dengan tingkat kreativitas siswa (lihat tabel 1 dan 2). Siswa yang mempunyai tingkat kreativitas baik, maka siswa tersebut dalam proses pembelajaran dapat mengembangkan sikap, kerjasama dan motivasi yang baik. Tercatat ada 11 siswa yang dapat mengembangkan sikap, kerjasama dan motivasi secara baik dalam proses pembelajaran (lihat tabel 1). Dari 11 siswa tersebut menunjukkan ada 8 siswa yang mencapai tingkat kreativitas tinggi/di atas rata-rata siswa kelas XII (lihat tabel 2). Hal ini menunjukkan bahwa proses pembelajaran memberikan arah bagi terciptanya kreativitas siswa. Dari 19 siswa kelas XII terdapat 11 siswa yang dapat mengembangkan sikap, kerjasama dan motivasi dalam proses pembelajaran, sehingga ada $58 \%$ siswa yang dapat menunjukkan sikap, kerjasama dan motivasi dalam proses pembelajaran. Sedangkan dari 11 atau $73 \%$ siswa yang mampu mengembangkan sikap, kerjasama dan motivasi dalam proses pembelajaran terdapat 8 siswa yang belum maksimal dalam mengembangkan sikap, kerjasama dan motivasi dalam proses pembelajaran atau mencapai $27 \%$ (lihat tabel 1).

Siswa yang memiliki ide, kreasi dan apresiasi yang baik akan mendorong kemampuan untuk meningkatkan prestasi belajar. Tingkat kreativitas yang tinggi akan menghasilkan prestasi belajar yang tinggi pula, Dari 19 siswa kelas XII terdapat 8 siswa yang menunjukkan tingkat kreativitas di atas rata-rata, yaitu mempunyai ide, kreasi dan apresiasi yang cukup balk. Dari 8 siswa tersebut ternyata juga dapat mengembangkan sikap, kerjasama dan motivasi yang tinggi dalam proses pembelajaran. Tingkat kreativitas yang dicapai siswa kelas XII adalah 8 siswa atau $42 \%$ dinyatakan baik, 9 siswa atau $47 \%$ dinyatakan cukup dan 2 siswa atau $11 \%$ dinyatakan kurang (lihat tabel 2).

Prestasi belajar yang dicapai siswa kelas XII menunjukkan bahwa terdapat 10 siswa atau $53 \%$ dinyatakan baik, 7 siswa atau $37 \%$ dinyatakan cukup dan 2 siswa atau $10 \%$ dinyatakan kurang (lihat tabel 3). Dari data tersebut menunjukkan adanya korelasi yang cukup signifikan antara tingkat kreativitas siswa terhadap prestasi belajar. Semakin baik tingkat kreativitas, maka akan semakin baik pula prestasi belajar yang dicapai siswa. Sebaliknya jika tingkat kreativitas rendah, maka prestasi belajar yang dicapai siswa juga akan rendah (lihat Tabel 4).

\section{Dampak Positif Kreativitas Terhadap Prestasi belajar}

Berdasarkan hasil penelitian menunjukkan bahwa kreativitas membawa dampak yang besar bagi perkembangan siswa dalam meningkatkan prestasi belajarnya. Dengan kreativitas, siswa mampu mencapai prestasi belajar secara maksimal. Beberapa dampak positif dari kreativitas, antara lain : 
a. Menemukan ide/gagasan baru. Dengan kreativitas yang baik, maka siswa dapat memunculkan ide/gagasan baru, sehingga akan sangat membantu kegiatan belajar mengajar dan meningkatkan prestasi belajar dan dapat menanamkan kemandirian.

b. Meningkatkan kreasi, Dengan kreativitas yang baik, maka siswa mampu menciptakan kreasi dalam mengikuti proses pembelajaran. Kreasi tersebut tidak hanya muncul saat proses pembelajaran di kelas, bahkan dalam lingkungan keluarga dan masyarakat. Kreasi ini dapat berupa keterampilan dalam menemukan model dan cara baru untuk ditonjolkan dalam lingkungan sekolah, keluarga dan masyarakat. Salah satu contoh adalah dalam pelajaran keterampilan dan kesenian dengan karya baru dan berbeda serta bervariasi. Dengan kreasi, maka siswa akan mampu meningkatkan prestasi belajarnya.

c. Meningkatkan Apresiasi. Siswa mampu mengapresiasikan setiap keadaan lingkungan yang dihadapinya, sehingga mudah baginya untuk menerima dan menemukan apa yang menjadi pokok pembicaraan. Dengan kreativitas yang baik, siswa akan mudah menerima setiap pelajaran dan mampu mengapresiasikan setiap pokok bahasan dalam penjiwaan. Perlu ditegaskan bahwa apresiasi merupakan salah satu aspek dalam mengembangkan kreativitas dalam belajar menguasai ilmu dan keterampilan, sehingga kreativitas dapat menjadi sarana untuk meningkatkan hasil belajar siswa.

d. Menumbuhkan rasa percaya diri. Ungkapan rasa percaya diri akan semakin terangsang dan tumbuh berkembang pada diri siswa karena dibangun melalui kerjasama, pergaulan, komunikasi dengan orang lain. Dengan kreativitas dapat menumbuhkan rasa percaya diri pada siswa, karena kreativitas mengajarkan siswa untuk mengutarakan ide/gagasan, memunculkan kreasi dan apresiasi. Hal ini akan berpengaruh terhadap prestasi belajar siswa, semakin baik kreativitas siswa maka akan semakin tumbuh rasa percaya diri dan akan bermanfaat bagi pencapaian prestasi belajar yang maksimal.

e. Menanamkan rasa tanggung jawab. Kreativitas dapat menanamkan rasa tanggung jawab bagi siswa, karena hasil kreativitas siswa akan membawa pengaruh terhadap proses pembelajaran dan prestasi belajar. Sehingga kreativitas menuntut siswa untuk giat belajar, mandiri dan punya rasa tanggung jawab terhadap apa yang telah menjadi cita-citanya.

f. Sikap dan tingkah laku yang baik. Pencerminan sikap dan tingkah laku yang baik adalah bagian dari kreativitas. Semakin baik kreativitas siswa, maka sikap dan tingkah laku siswa tersebut dapat terkontrol terutama dalam proses pembelajaran (lihat tabel 4).

g. Nilai sosial. Pendidikan sosial dalam proses pembelajaran akan tampak dengan adanya sikap, kerjasama antar siswa dalam suasana yang demokratis, kerjasama antara siswa dan guru serta seluruh keluarga sekolah sehingga menciptakan suatu kehidupan dan pelayanan sosial yang sehat. Dengan kreativitas, siswa dapat melakukan semua itu tanpa rasa takut, pesimis dan rendah diri.

h. Menumbuhkan, rasa disiplin. Ratarata siswa yang kreatif adalah siswa yang mampu mengembangkan 
sikap disiplin. Pada tabel 4 menunjukkan bahwa siswa yang mempunyai kreativitas baik, maka ia akan semakin disiplin dalam proses pembelajaran. Sehingga dengan rasa disiplin, siswa akan menjalankan setiap kewajibannya dengan tepat waktu. Hal ini akan membantu siswa dalam mencapai prestasi belajar yang maksimal.

\section{Kontribusi Kreativitas Terhadap Prestasi Belajar \\ Kreativitas memberikan} kontribusi yang cukup signifikan terhadap prestasi belajar Siswa. Semakin tinggi tingkat kreativitas siswa, maka akan semakin baik prestasi belajar yang dicapai siswa tersebut. Sebaliknya jika siswa kurang memiliki kreativitas, maka akan semakin rendah prestasi belajar yang diperoleh siswa tersebut.

Korelasi antara proses pembelajaran, tingkat kreativitas dan prestasi belajar siswa ternyata saling terkait dan mendukung. Pada tabel 1 menunjukkan bahwa semua siswa yang mempunyai sikap, kerjasama dan motivasi yang baik dalam proses pembelajaran akan mempunyai ide, kreasi dan apresiasi yang baik pula dalam tingkat kreativitasnya (lihat tabel 2).

Dengan tingkat kreativitas yang tinggi, maka siswa mampu meningkatkan prestasi belajarnya (lihat tabel 4). Semua siswa yang memiliki ide, kreasi dan apresiasi yang baik dalam kreativitasnya, maka siswa tersebut pasti dapat mencapai prestasi belajar yang baik (lihat tabel 4). Dengan demikian jelas bahwa kreativitas memberikan kontribusi terhadap prestasi belajar siswa. Kontribusi tersebut berupa kemampuan siswa dalam mencetuskan ide/gagasan, berkreasi dalam setiap mata pelajaran dan mampu mengapresiasikan setiap mata pelajaran yang telah diberikan, sehingga mudah bagi siswa tersebut untuk mengikuti, menerima dan mengerti setiap pelajaran yang diberikan dan akhirnya dapat memberikan prestasi belajar yang memuaskan.

Kontribusi kreativitas terhadap prestasi belajar siswa kelas XII dapat menjadi modal untuk dapat melanjutkan pada jenjang pendidikan yang lebih tinggi. Untuk meningkatkan mutu pendidikan, siswa diharapkan dapat mengembangkan kreativitas sejak dini. Peranan guru, orang tua dan masyarakat akan sangat membantu dalam pengembangan kreativitas anak. Dengan bekal kreativitas yang tertanam saat di bangku, maka siswa akan lebih siap untuk bersaing dan melanjutkan ke jenjang pendidikan yang lebih tinggi.

\section{KESIMPULAN DAN SARAN Kesimpulan}

Berdasarkan rumusan-masalah dan pembahasan tentang Kreativitas Meningkatkan Prestasi Belajar Dalam proses Belajar Mengajar pada Siswa Kelas XII SMA Negeri 1 Ambunten, maka dapat ditarik kesimpulan.

a. Kreativitas berpengaruh terhadap prestasi belajar siswa kelas XII SMA Negeri 1 Ambunten. Kenyataan ini menunjukkan bahwa semua siswa kelas XII yang memiliki kreativitas baik, maka siswa tersebut mampu mencapai prestasi belajar yang maksimal. Sedangkan siswa yang memiliki kreativitas rendah, maka prestasi belajar yang diperoleh siswa tersebut akan rendah,

b. Kreativitas memberikan dampak positif terhadap prestasi belajar siswa kelas XII SMA Negeri 1 Ambunten. Dampak positif kreativitas bagi siswa antara lain : menemukan ide/gagasan baru, meningkatkan kreasi, meningkatkan apresiasi, menumbuh- 
kan rasa percaya diri, menanamkan rasa tanggung jawab, menanamkan sikap dan tingkah laku yang baik, menciptakan nilai sosial dan menumbuhkan rasa percaya diri.

c. Kreativitas memberikan kontribusi yang positif terhadap prestasi belajar siswa kelas XII SMA Negeri 1 Ambunten dalam upaya melanjutkan pendidikan ke jenjang yang lebih tinggi. Kontribusi kreativitas berupa ide/gagasan, kreasi dan apresiasi dalam setiap mata pelajaran yang diajarkan.

\section{Saran}

Berdasarkan kesimpulan hasil penelitian yang menunjukkan adanya pengaruh kreativitas terhadap prestasi belajar siswa kelas XII SMA Negeri 1 Ambunten, maka ada beberapa saran yang perlu diperhatikan, antara lain:

a. Dalam proses pembelajaran diharapkan para guru mampu menerapkan metode pengajaran yang dapat menumbuhkan kreativitas siswa.

b. Peranan guru, orang tua dan masyarakat diharapkan ikut mendorong siswa untuk meningkatkan kreativitas melalui ide, kreasi dan apresiasinya.

c. Guna mencapai prestasi belajar yang maksimal, maka siswa, guru dan orang tua hendaknya mengarahkan siswa untuk dapat mengembangkan sikap, kerjasama dan motivasi dalam proses pembelajaran.

d. Dengan adanya hubungan yang cukup signifikan antara proses pembelajaran, kreativitas dan prestasi belajar siswa, maka diharapkan bagi semua pihak yang terlibat dalam pengelolaan pendidikan dasar untuk memperhatikan proses pembelajaran dan kreativitas yang dimiliki siswa. Sehingga dapat mendukung bagi tercapainya tujuan pendidikan dengan hasil yang memuaskan.
DAFTAR PUSTAKA

Amien, Moh. 1980, Peranan Kreativitas dalam Pendidikan, Analisis Pendidikan. Depdikbud. Jakarta.

Bafadal. I. 1994. Proses Perubahan di Sekolah. Desertasi. Program Pasca Sarjana IKIP Malang.

2003. Manajemen Perlengkapan Sekolah. Teori dan Aplikasinya. Jakarta: PT Bumi Aksara.

Bogdan, R. C., \& Biklen, S. K. 1982. Qualitative Research In Education. Boston: Allyn \& Bacon.

Cohen, Louis. 1976. Educational Research in Classroom and Schools : A Manual of Materials and Methods. London : Harper \& Row Publishers.

Depdiknas. 2003. Kurikulum Berbasis Kompetensi Dalam Menunjang Kecakapan Hidup Siswa. Dirjen Dikdasmen Direktorat Tenaga Kependidikan. Jakarta.

Dick, W., dan Carey, L. 1985. The Systematic Design of Instruction. Second Edition. Dallas, Texas: Scott, Foresman dan Company.

1977. Formative Evaluation. Dalam Leslie Briggs (Ed.). Instructional Design : Principle and Applications. New Jersey : Educational Technologi Puplications Englewood Cliffs, 311-333.

Getzels, J W, dan Philip W J. 1962. Creativity and Intelligence: Exploration With Gifted Students. London \& New York: John Wiley \& Sons, Inc.

Guilford, J P. 1964. Creative Abilities in the Art. Dalam Mednick, Martha T., dan Samoff A. Mednick (Ed.). Research in Personality. New York, Chicago, San Fransisco, Toronto, London, USA : Holt, Rindhart and Winston, Inc.

Hamalik, O. 2001. Proses Belajar Mengajar. Jakarta: PT Bumi Aksara. 
Moleong, L. J. 1995. Metodologi Penelitian Kualitatif. Bandung PT. Remaja Rosdakarya.

Moleong, L.J. 2000. Metodologi Penelitian Kualitatif. Bandung PT. Remaja Rosdakarya.

Nasution, S. 1987. Berbagai Pendekatan Dalam Proses Belajar dan Mengajar. Jakarta: PT. Bina Aksara.

Poerbakawaca, Soeganda. 1975. Suatu Pemikiran Mengenai Pendidikan di Indonesia. Jakarta: Yayasan Idayu.

Sukirin. 1984. Psikologi Belajar. Yogyakarta: HP - IKIP Yogyakarta.

Winarno, S. 1985. Pengantar Penelitian ilmiah. Bandung : Tarsito.

Winkel. 1984. Psikologi Pendidikan dan Evaluasi Belajar. Jakarta: Gramedia.

Zuriah, N. 2003. Penelitian Tindakan dalam Bidang Pendidikan dan Sosial. Edisi Pertama. Malang: Bayu Media Publishing. 
Jurnal Lentera Sains (Lensa)

20 Jurnal Lensa, Volume 5 Jilid II November 2015 